\title{
Suppression of Tobacco Basic Chitinase Gene Expression in Response to Colonization by the Arbuscular Mycorrhizal Fungus Glomus intraradices
}

\author{
Rakefet David, ${ }^{1}$ Hanan Itzhaki, ${ }^{2}$ Idit Ginzberg, ${ }^{1}$ Yedidya Gafni, ${ }^{1}$ Gad Galili, ${ }^{2}$ and Yoram Kapulnik ${ }^{1}$ \\ ${ }^{1}$ Institute of Field and Garden Crops, ARO, The Volcani Center, Bet Dagan 50250, Israel; and ${ }^{2}$ Department \\ of Plant Genetics, The Weizmann Institute of Science, Rehovot 76100, Israel \\ Accepted 28 February 1998.
}

\begin{abstract}
A differentially displayed cDNA clone (MD17) was isolated from tobacco roots (Nicotiana tabacum cv. Xanthi-nc) infected with the arbuscular mycorrhizal (AM) fungus Glomus intraradices. The isolated DNA fragment exhibited a reduced level of expression in response to $\mathrm{AM}$ establishment and $90 \%$ identity with the $3^{\prime}$ noncoding sequence of two basic chitinases (EC 3.2.1.14) from N. tabacum. Northern (RNA) blots and Western blots (immunoblots), probed with tobacco basic chitinase gene-specific probe and polyclonal antibodies raised against the chitinase enzyme, yielded hybridization patterns similar to those of MD17. Moreover, the up-regulation of the 32-kDa basic chitinase gene expression in tobacco roots by $(1,2,3)$ thiadiazole-7-carbothioic acid S-methyl ester (BTH) was less effective in mycorrhizal roots than in nonmycorrhizal controls. Suppression of endogenous basic chitinase (32kDa) expression was also observed in transgenic mycorrhizal plants that constitutively express the 34-kDa basic chitinase $A$ isoform. When plants were grown with an increased phosphate supply, no suppression of the 32-kDa basic chitinase was obtained. These findings indicate that during the colonization and establishment of $G$. intraradices in tobacco roots, expression of the basic chitinase gene is down-regulated at the mRNA level.
\end{abstract}

Additional keywords: pathogen-related (PR) proteins, symbiosis.

Arbuscular mycorrhizal (AM) fungi are ubiquitous soil inhabitants, forming an obligate and nonspecific symbiotic relationship with the roots of most terrestrial plants (BonfanteFasolo 1988). Fungal establishment in the host roots involves a complex sequence of events and intracellular modifications (Bonfante-Fasolo and Perotto 1992). To date, little is known of the molecular mechanisms involved in the development of

Corresponding author: Yoram Kapulnik, Institute of Field and Garden Crops, ARO, The Volcani Center, Bet Dagan 50250, Israel

Telephone: (972) 3-968-3488; Fax: (972) 3-966-9642

E-mail: Kapulnik@ Agri.Huji.ac.IL

Present address of Hanan Itzhaki: The Institute for Applied Research, Ben Gurion University of the Negev, Beer-Sheva, Israel

Contribution from the Agricultural Research Organization, The Volcani Center, Bet Dagan, Israel. No. 2045-E, 1997 series. the symbiosis. Most initial efforts have been directed toward analyzing the expression of plant-defense genes in response to AM fungal colonization (Lambais and Mehdy 1993; Harrison and Dixon 1994; Volpin et al. 1995; Blee and Anderson 1996; Kapulnik et al. 1996).

Plant chitinases, lytic enzymes that catalyze the hydrolysis of chitin, are known to exhibit constitutive activity in many plant tissues, but their expression is also induced during plant infection by pathogenic organisms (Boller 1987; Collinge et al. 1993) or stimulated by abiotic elicitation (Boller 1988). Chitinase is considered to be an important component of the plant defense system. In in vitro experiments, chitinase has shown the ability to partially hydrolyze isolated fungal cell walls (Boller et al. 1983) and to inhibit growth of certain phytopathogenic fungi (Schlumbaum et al. 1986). In tobacco, there are several classes of chitinases, class I of which consists of a basic, vacuolar isoform, and class II an acidic, extracellular isoform (Lawton et al. 1992). A basic chitinase gene has been found to be constitutively expressed at high levels in tobacco roots, and to increase cumulatively with plant age (Neale et al. 1990). Moreover, transgenic plants constitutively expressing a heterologous chitinase gene have been shown to exhibit increased resistance to root pathogens (Broglie et al. 1991; Sela-Buurlage et al. 1993; Vierheilig et al. 1993).

Mycorrhizal fungi involved in plant-fungus symbioses contain chitin in their cell walls (Smith and GianinazziPearson 1988) and may, therefore, be influenced by the chitinases produced in the root of the host plant, especially in the early stages of AM infection. However, plant chitinases do not appear to come into direct contact with or bind to external mycorrhizal hyphae (Spanu et al. 1989). Constitutive expression of the tobacco basic chitinase in transgenic Nicotiana sylvestris plants did not affect the colonization of roots by the mycorrhizal fungus Glomus mosseae (Vierheilig et al. 1993). The specific activity of Allium porrum chitinase from roots infected by $G$. versiforme increased above that of noninfected roots during the first stage of colonization. However, when the symbiosis was fully established, the specific activity of the chitinase in mycorrhizal roots was below that in control roots (Spanu et al. 1989). Similar results were obtained with alfalfa roots colonized with $G$. intraradices (Volpin et al. 1994). Nevertheless, colonization of tobacco and Pisum sativum L. roots by different Glomus spp. resulted in the formation of additional, new, acidic chitinase isoforms in the inoculated 
roots (Dumas-Gaudot et al. 1992, 1994). Transient induction followed by down-regulation of endochitinase activity and the steady-state level of mRNAs encoding basic and acidic chitinases have also been observed in mycorrhizal fungusinfected Phaseolus vulgaris (Lambais and Mehdy 1993).

Here we report the suppression of tobacco basic chitinase (32-kDa) expression in mycorrhizal roots, as identified by dif-

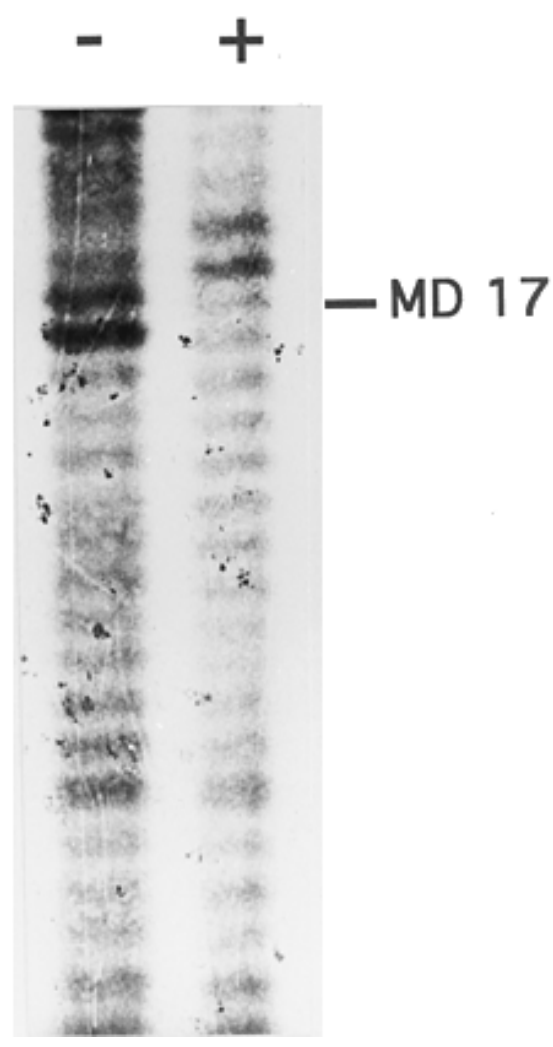

Fig. 1. Isolation of MD17. Differential display of RNA from 42-day-old mycorrhizal (+) and nonmycorrhizal (-) tobacco roots. Down-regulated mycorrhizal band, MD17, is indicated. ferential-display assay, and analyses of the mRNA steadystate level and protein level. Moreover, chemical induction of the $32-\mathrm{kDa}$ basic chitinase gene by $(1,2,3)$-thiadiazole-7carbothioic acid S-methyl ester (BTH) was suppressed in mycorrhizal roots but not in nonmycorrhizal controls, suggesting that AM fungi down-regulate transcription of the $32-\mathrm{kDa}$ basic chitinase.

\section{RESULTS}

\section{Isolation and identification of a differentially displayed tobacco basic chitinase fragment.}

To study plant-gene expression during the establishment of AM fungi in N. tabacum roots, a differential display method was applied. An approximately 55-nucleotide-long DNA band was found to be significantly less intense in the mycorrhizal roots than in noninfected roots (Fig. 1). This band, designated MD17 (mycorrhizal down-regulated band no. 17), was polymerase chain reaction (PCR) re-amplified, subcloned into pBluescript, and sequenced. The resultant 138-bp cloned fragment was longer than the original, differentially displayed DNA fragment. Sequence analysis showed repetition of the primers used within that cDNA, dividing it into three segments: nucleotides 1 to 53,54 to 84 , and 85 to 138 (Fig. 2A). MD17 may have resulted from co-ligation of these three segments. The 3' segment of MD17, nucleotides 85 to 130, was found to share $90 \%$ identity in nucleotide sequence with the $3^{\prime}$ noncoding sequence of two basic chitinase genes from $N$. tabacum (Shinshi et al. 1990; Fukuda et al. 1991) (Fig. 2B).

Northern (RNA) blot studies were performed to verify differential expression of MD17 and the homology between the down-regulated sequence in MD17 and the tobacco basic chitinase genes. Total RNA extracts, isolated from 42-day-old AM-infected and noninfected roots, were probed with (i) the MD17 isolated fragment, (ii) an oligomer encoding nucleotides 102 to 127 of the MD17 fragment, or (iii) $5^{\prime}$ tobacco basic chitinase-specific probe (ChitB) encoding the N-terminal cysteine-rich "hevein" domain and the hinge region (Payne et al. 1990; Collinge et al. 1993), and (iv) a tomato rDNA frag-

A

1 TTTTTTTTTTTCCACGTCACAAGAAGGAGACCTAAGCATCGGCCTACGTCAC 53

54 GTGACGTAGGAAAGCATGTGGAAAAAAAAAG 84

85 GTGACGTGGGGACCAGGGGCTATGAATAAAGTTAATGTGTGACGTGGAAAAAA 138

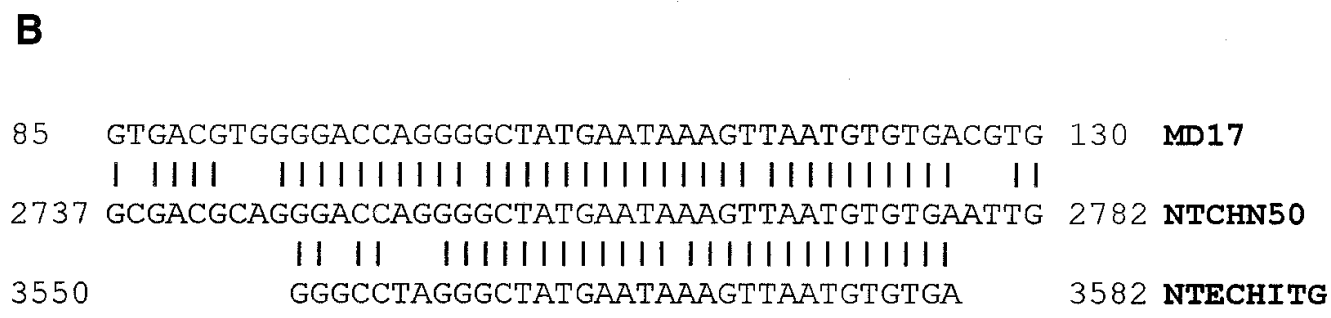

Fig. 2. Sequence analysis of MD17. A, Nucleotide sequence of MD17, arranged as the three co-ligated fragments, according to the primer repeats, which are underlined. B, Sequence homology of the MD17 3'-end fragment to two tobacco basic chitinase genes: NTCHN50, GenBank accession no. X51599, and NTECHITG, GenBank accession no. X16938. 
ment. Hybridization signals yielded by all of the first three probes were significantly lower in the mycorrhizal roots than in the nonmycorrhizal control roots (Fig. 3), implying that the unique down-regulation pattern of the MD17 fragment corresponds to that of the tobacco basic chitinase genes.

To rule out the potential of cross hybridization between the tomato rDNA probe to the fungal ribosomal RNA sequences a Southern blot analysis was performed. A significant hybridization signal was obtained with the genomic DNA of N. tabacum cv. Xanthi-nc but not with DNA from $G$. intraradices spores (Fig. 4), eliminating the possibility of crosshybridization between the tomato rDNA probe and the corresponding fungal rRNA.

The reduced level of the basic chitinase transcript in mycorrhizal roots was further confirmed with transgenic tobacco plant constitutively expressing the chimeric $\beta$-glucuronidase (GUS) gene fused to the cauliflower mosaic virus (CaMV) $35 \mathrm{~S}$ promoter, by means of Northern blot analysis (Fig. 5). A similar hybridization signal was obtained in mycorrhizal and

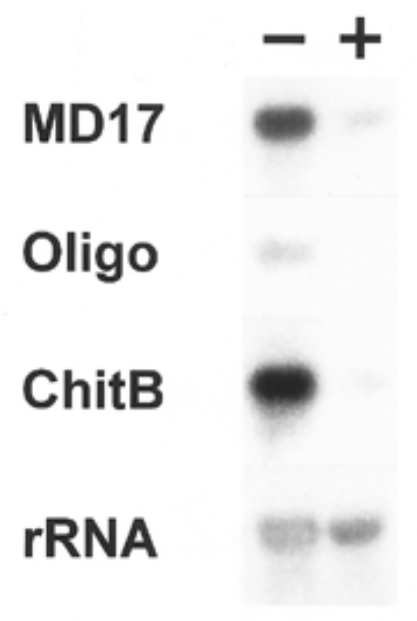

Fig. 3. Identification of MD17. Northern (RNA) blot with total RNA from mycorrhizal $(+)$ and nonmycorrhizal $(-)$ tobacco roots was probed with MD17, an oligomer homologous to the $3^{\prime}$ end of MD17, 5' end of tobacco basic chitinase gene-specific fragment (ChitB), and tomato rDNA.

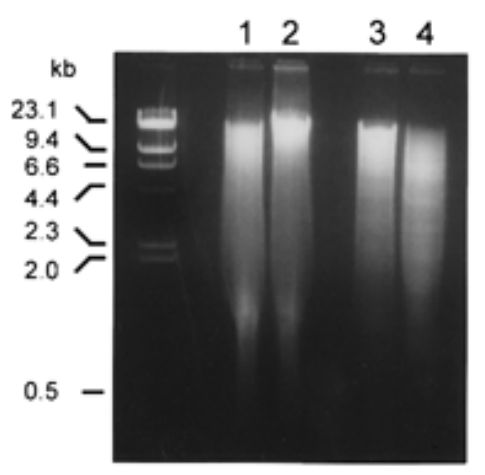

12

34

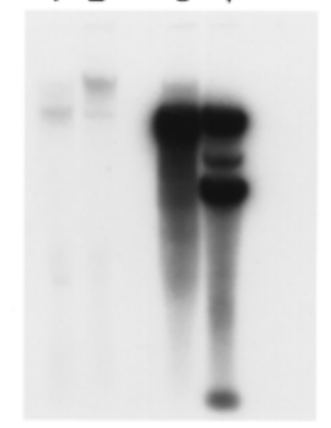

Fig. 4. Detection of ribosomal RNA genes. Southern analysis of 2- $\mu \mathrm{g}$ DNA samples from Glomus intraradices spores $(1,2)$ and Nicotiana tabacum cv. Xanthi-nc $(3,4)$, digested with BamHI $(1,3)$ or EcoRI $(2,4)$ and probed with tomato rDNA (on the left). Ethidium bromide staining of the samples and HindIII digestion of phage lambda as size marker are shown on the right. nonmycorrhizal roots, for both the rRNA and the GUS transcripts; however, the signal obtained for the basic chitinase transcript in the mycorrhizal roots was significantly lower (Fig. 5A). The signal intensities (obtained by PhosphorImager) for the basic chitinase transcripts were calculated relative to those of the rRNA or the constitutively expressed GUS. In mycorrhizal root samples, a comparable magnitude of reduction was obtained for both reference genes (Fig. 5B). These results indicate that the estimation of transcript level upon rRNA value in our experimental system was valid.

\section{Down-regulation of tobacco basic chitinase transcript level.}

In order to follow basic chitinase gene transcription during the development of the symbiosis, total RNA was extracted from mycorrhizal and nonmycorrhizal root segments taken from the infection zone ( 3 to $4 \mathrm{~cm}$ below the soil surface, see Materials and Methods). The G. intraradices-inoculated roots of 25-, 35-, and 45-day-old plants showed colonization rates of 27,52 , and $82 \%$, respectively. In Northern assays, at all ages, hybridization with the 228-bp ChitB was found to be weaker with RNA isolated from mycorrhizal roots, compared
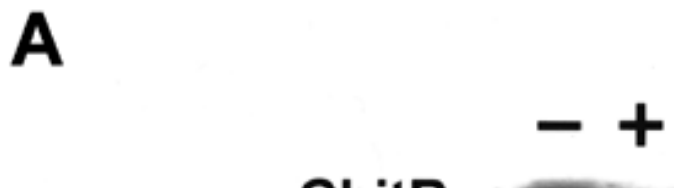

ChitB

\section{GUS}

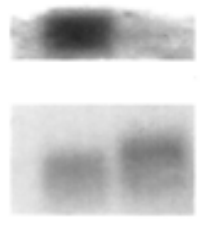

rRNA

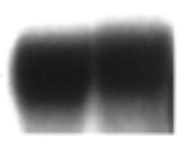

B

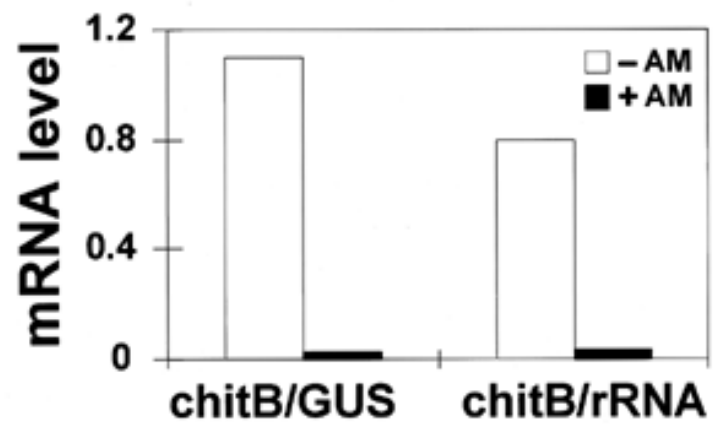

Fig. 5. Determination of basic chitinase transcripts level. Northern (RNA) blot with $10 \mu \mathrm{g}$ of total RNA from mycorrhizal (+) and nonmycorrhizal (-) roots of 37-day-old transgenic tobacco plants, constitutively expressing $\beta$-glucuronidase (GUS). Total RNA was hybridized with $5^{\prime}$ tobacco basic chitinase-specific probe (ChitB), GUS, and tomato rRNA probes (A). Radioactivity values were analyzed with the Phosphor-Imager program, and basic chitinase transcripts level was normalized according to the GUS mRNA or rRNA content of each sample (B). 
with samples from nonmycorrhizal roots (Fig. 6A). Transcript levels were about 2 to 4 times lower in RNA samples extracted from $G$. intraradices-colonized roots than in those from the noncolonized tissue, on each of the three independent sampling dates (Fig. 6B). To further confirm the effect of mycorrhizal colonization on the steady-state level of the basic chitinase transcript, plants were treated with BTH, a chemical activator of systemic-acquired resistance (SAR) and an inducer of pathogen-related (PR) proteins (Friedrich et al., 1996). BTH was applied when plants were 21 days old, and the level of the basic chitinase transcript was detected 4, 14, and 24 days thereafter. When plants were treated with $\mathrm{BTH}$, no effect on the rate of AM fungus colonization in the roots was observed (data not shown), but the steady-state level of the basic chitinase transcript was significantly lower in BTHtreated mycorrhizal plants than in the BTH-treated controls (Fig. 6A, B).

\section{Suppression of tobacco basic chitinase protein level.}

Several Western blot (immunoblot) analyses were used to investigate the expression of the basic chitinase in mycorrhizal and nonmycorrhizal roots of tobacco plants. Protein extraction from root segments was carried out with the same samples utilized in the Northern studies (described above). Levels of the $32-\mathrm{kDa}$ protein from nonmycorrhizal roots increased with plant age (Fig. 7), indicating accumulation of this protein in tobacco roots, as reported previously by Neale et al.
(1990). However, in mycorrhizal roots, no accumulation of this protein was observed (Fig. 7). When plants were treated with BTH, significant accumulation of the basic chitinase protein was observed in the control plants. The level of this protein in the BTH-treated mycorrhizal plants was significantly lower than that in the controls on the first date of sampling (day 25) and thereafter (Fig. 7). These data were consistent with the detection of basic chitinase transcript in the mycorrhizal roots, and indicated that $G$. intraradices colonization in the roots involves an active suppression mechanism(s) that was able to partially reduce the BTH chemical induction.

To verify that the lower accumulation of the $32-\mathrm{kDa}$ basic chitinase in AM-colonized roots did not result from the biotic supply of phosphate $(\mathrm{P})$ via the AM fungus, plants were treated with a high level of $\mathrm{P}(1 \mathrm{mM})$. Phosphate was applied when plants were 21 days old, and at the day of harvest (45day-old plants) the AM fungus colonization rates were 32 and $74 \%$ for high- and low-P-treated plants, respectively. At the low $\mathrm{P}$ level $(0.1 \mathrm{mM})$, a reduction in the $32-\mathrm{kDa}$ basic chitinase level was obtained in mycorrhizal roots, whereas at the enhanced P level no such reduction was obtained (Fig. 8). This observation implies that the unique down-regulation phenomenon observed in the current study was not related to the elevated P level in the plant, since application of $1 \mathrm{mM} P$ impaired this phenomenon in mycorrhizal roots.

To test whether overexpression of a tobacco basic chitinase gene could interfere with AM fungal establishment or the 32-

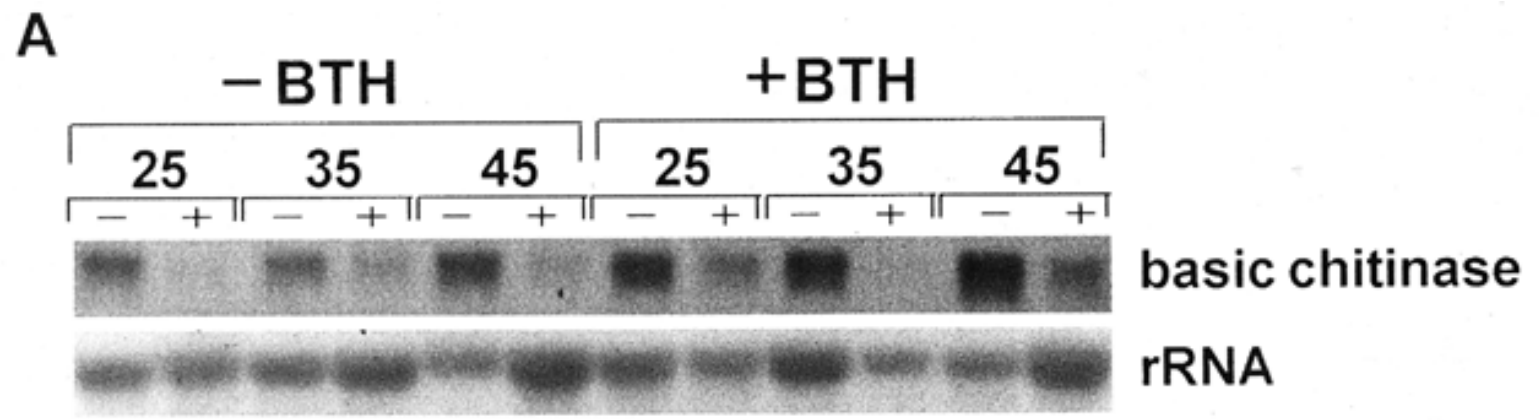

B

$-\mathrm{BTH}$

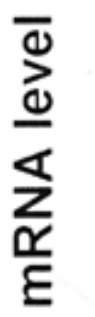

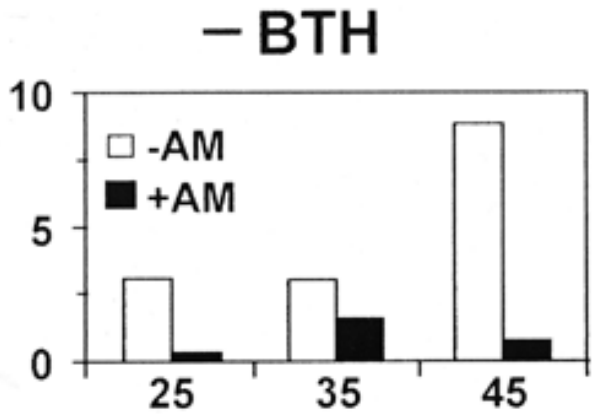

Time
$+\mathrm{BTH}$

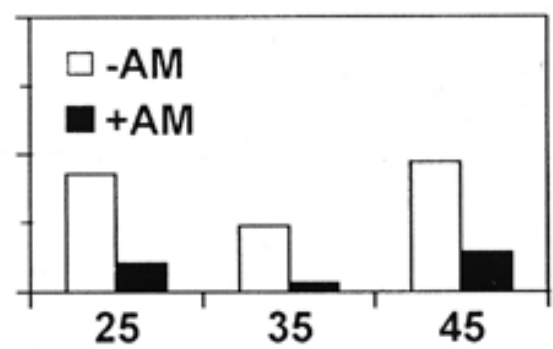

Time

Fig. 6. Expression of tobacco basic chitinase. Northern (RNA) blot with $10 \mu \mathrm{g}$ of total RNA from mycorrhizal (+) and nonmycorrhizal (-) tobacco roots, treated $(+)$ or nontreated $(-)$ with $(1,2,3)$-thiadiazole-7-carbothioic acid S-methyl ester (BTH), 25, 35, and 45 days after germination, probed with $5^{\prime}$ tobacco basic chitinase-specific probe (ChitB), and with tomato rDNA (A). Radioactivity values were analyzed with the Phosphor-Imager program, and normalized according to the rRNA content of each sample. The tobacco basic chitinase mRNA steady-state level in mycorrhizal roots (black boxes) was compared with its level in nonmycorrhizal roots (white boxes) (B). 
$\mathrm{kDa}$ chitinase suppression phenomenon, transgenic $N$. sylvestris plants that constitutively expressed the 34-kDa tobacco basic chitinase A isoform (Neuhaus et al. 1991; van Buuren et al. 1992) were used. This line (1794C9-1; Alexander et al. 1993) together with $N$. tabacum cv. Xanthi-nc plants were infected with $G$. intraradices to the same colonization rate of $80 \%$, and accumulation of the $34-\mathrm{kDa}$ transgene protein was observed in both mycorrhizal and nonmycorrhizal roots (Fig. 9). However, the level of the endogenic $32-\mathrm{kDa}$ chitinase was significantly reduced by the mycorrhizal fungal colonization (Fig. 9). Overexpression of the 34-kDa basic chitinase gene did not interfere either with the colonization pattern of the fungal symbiont or with the suppression of the $32-\mathrm{kDa}$ isoform. These results support the suggestion that the lower level of basic chitinase in the mycorrhizal roots is not a post-translational event but may represent a promoter regulation of gene expression in response to colonization by $G$. intraradices.

\section{DISCUSSION}

In a search for specific root mRNAs whose expression is altered in response to colonization by the mycorrhizal fungus G. intraradices, a cDNA fragment, MD17, homologous to the $3^{\prime}$ end of tobacco basic chitinase genes, was identified. This fragment was co-isolated with additional molecules of similar lengths (Fig. 2A), and the corresponding transcript was found to be significantly less intensely detected in mycorrhizal than in control roots (Fig. 3). Sequence analysis revealed that the 45 nucleotides at the $3^{\prime}$ end of MD17 share high identity with tobacco basic chitinase genes. A short oligomer identical to these nucleotides exhibited the same hybridization pattern as MD17. Moreover, the same hybridization pattern was also obtained with the $5^{\prime}$ end of a tobacco basic chitinase gene probe prepared from pCHN50 (Shinshi et al. 1987). Taken together, these results indicate that the differentially displayed MD17 fragment represents the tobacco basic chitinase gene, which is down-regulated during AM colonization. A reduction in basic chitinase gene expression in mycorrhizal roots has been previously described in $G$. intraradices-colonized bean, in the later stages of colonization (Lambais and Mehdy 1993).

The reduction in the steady-state level of tobacco chitinase gene mRNA during mycorrhizal colonization was associated with a significant reduction in the level of a $32-\mathrm{kDa}$ tobacco basic chitinase, compared with its level in nonmycorrhizal roots. The reduction in basic chitinase level was apparent during active colonization stages of the mycorrhizal fungi in roots $(0.1 \mathrm{mM} \mathrm{P})$, but could not be mimicked by abiotic $\mathrm{P}$ supply to noninfected plants (Fig. 8). Application of $1 \mathrm{mM} \mathrm{P}$ after 3 weeks of plant growth arrested mycorrhization and impaired the down-regulation phenomenon. Basic chitinase reduction could be detected prior to any signs of the effects of symbiosis (e.g., increased plant growth, mineral contents, etc.; data not shown), and it corresponds to the reduction in chitinolytic enzyme activity of mycorrhizal roots reported in other experimental systems (Spanu et al. 1989; Lambais and Mehdy 1993; Volpin et al. 1994).

Certain chemicals have been shown to induce the accumulation of mRNAs encoding PR proteins that provide protection against specific groups of pathogens (Friedrich et al. 1996). BTH applied exogenously to leaves has been shown to be translocated throughout the plant, to elicit a signaltransduction pathway, and to induce the expression of genes encoding PR proteins (Friedrich et al. 1996); application of BTH to plant roots significantly induced accumulation of the 32-kDa basic chitinase (Fig. 7). The fact that this induction was suppressed by AM-fungal colonization implies the specific down-regulation of a pathway involved in the basic chitinase gene expression. Whether a product(s) of symbiosis-related genes affects expression of the basic chitinase gene directly or whether the genes act via the activation of fungus-derived suppressers remains to be elucidated. We previously demonstrated biochemical changes induced in inoculated but not colonized roots of alfalfa plants by the presence of $G$. intraradices in the host rhizosphere; an apparent colonization of the tissue was not required (Volpin et al. 1994). It has been hypothesized that plant cells recognize elicitors derived from AM fungi via unknown binding sites (Gianinazzi-Pearson et al. 1995). It is important to note that the suppression phenomenon observed in the present study was not correlated with the colonization rate of the fungus in the roots: similar suppression intensities were observed for colonization rates of 27,52 , and $82 \%$. It is reasonable to suggest that the suppression phenomenon is stimulated by a plant-mediated regulator that is elicited by the host during fungal colonization, rather than by elicitor-mediated signal transduction for defense responses contrived by the fungus. The fact that some of the chitinase isoforms are induced in tobacco roots in response to mycorrhizal fungi (DumasGaudot et al. 1992, 1994), while others are suppressed (present study; Spanu et al. 1989; Lambais and Mehdy 1993; Volpin et al. 1994), is indicative of a mechanism(s) by which AM-fungal suppression is more specific and may be

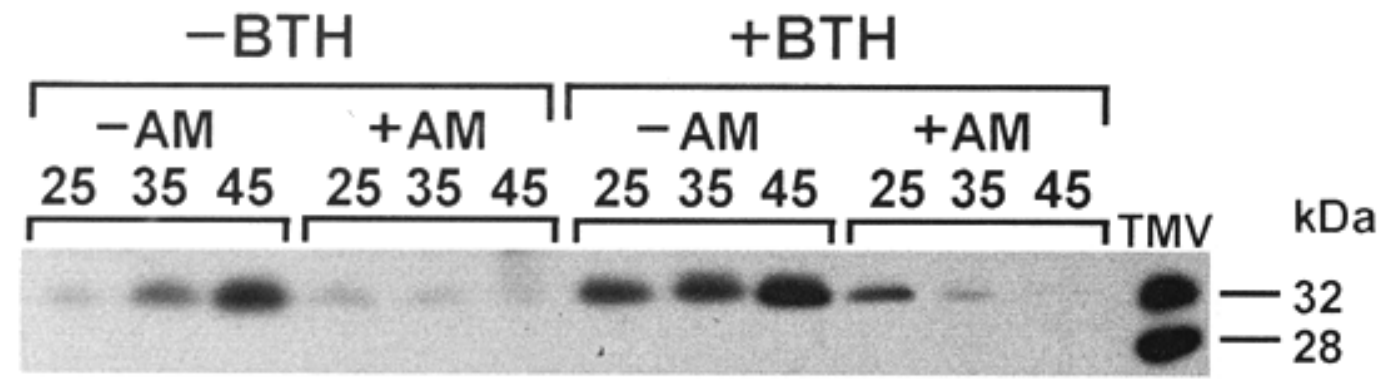

Fig. 7. Steady-state level of 32-kDa tobacco basic chitinase. Proteins were extracted from roots of mycorrhizal (+) and nonmycorrhizal (-) tobacco plants, treated (+) or nontreated (-) with (1,2,3)-thiadiazole-7-carbothioic acid S-methyl ester (BTH), 25, 35, and 45 days after germination. Samples (10 $\mu \mathrm{g}$ ) were analyzed by Western blot (immunoblot) probed with polyclonal antibodies directed against tobacco chitinase. The $32-\mathrm{kDa}$ basic chitinase and 29-kDa acidic chitinase, extracted from leaves infected with tobacco mosaic virus (TMV), are indicated. 
different from a general role of cell-wall components in eliciting responses. However, to date, this is only conjecture: further studies, using specific molecular probes of specific chitinases to compare between infections by root pathogens and those by AM fungi, would improve our understanding of the role of suppression mechanisms in the interaction between plant roots and the microsymbiont fungus.

In contrast to many pathogenic interactions, AM associations are characterized by fungal growth within the host, and avoidance or inactivation of plant-defense mechanisms (Bonfante-Fasolo and Perotto 1992). Specific plant chitinases can degrade fungal cell walls, thereby limiting the spread of pathogens in the infected plant (Graham and Sticklen 1994). A basic chitinase gene is constitutively expressed at high levels in tobacco roots and its mRNA levels have been shown to increase with plant age (Neale et al. 1990). It is tempting to speculate that the reduction in basic chitinase gene expression observed in mycorrhizal plants simply reflects suppression of the chitinolytic potential of the roots, to enable better establishment of the fungus within them. However, basic chitinase is localized in the plant-cell vacuole, and the periarbuscular membrane does not permit direct contact of the AM fungus with intracellular structures. In any event, chitinase does not appear to bind to external AM hyphae (Spanu et al. 1989). Transgenic tobacco plants that constitutively expressed basic chitinase were equally well colonized by $G$. mosseae (Vierheilig et al. 1995) and by G. intraradices (Fig. 9; R. David, Y. Cohen, and Y. Kapulnik, unpublished data). In light of all these findings, prevention of the host's basic chitinase gene expression may not be an essential step in AM-fungal colonization of tobacco roots, but may nevertheless be important for fungal development and morphogenesis in the colonized tissue.

Although the role of chitinase activity in the AM symbiotic association is not clear, the reduced level of tobacco basic chitinase in mycorrhizal roots could be explained by alteration in plant hormonal levels observed at the time of the AMfungal colonization (Spanu et al. 1989). The plant hormones auxin and cytokinin appear to have a suppressive effect on chitinase levels in tobacco cells (Shinshi et al. 1987). Cytokinin may modify mRNA stability, and chitinase gene expression may be affected post-transcriptionally as well as transcriptionally (Graham and Sticklen 1994). While the mechanism and reason for the differential expression of the tobacco chitinase genes are currently unknown, the available evidence that mycorrhizal colonization modifies gene activation and expression in the host plant may imply the exis-

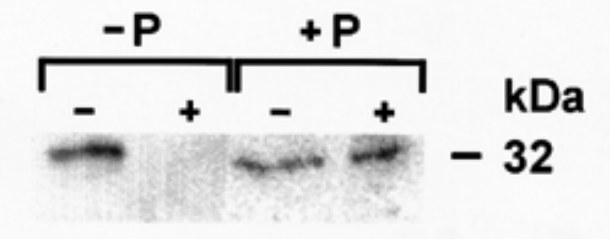

Fig. 8. Effect of phosphorus levels on the $32-\mathrm{kDa}$ tobacco basic chitinase. Mycorrhizal (+) and nonmycorrhizal (-) tobacco plants were watered with $0.1 \mathrm{mM} \mathrm{P}(-\mathrm{P})$ or $1 \mathrm{mM} \mathrm{P}(+\mathrm{P})$ in the nutrient solution and plants were sampled 45 days after sowing. Protein samples $(10 \mu \mathrm{g})$ were analyzed by Western blot (immunoblot) probed with polyclonal antibodies directed against tobacco chitinase. tence/occurrence of a recognition process and/or transaction event(s) during the establishment of AM symbiosis.

\section{MATERIALS AND METHODS}

\section{Plant culture.}

Surface-sterilized seeds of N. tabacum cv. Xanthi-nc were grown under axenic conditions (Patterson et al. 1990) in 0.5$\mathrm{kg}$ pots containing autoclaved sand. Plants (5 to 7 seedlings per pot) were grown in a greenhouse (14/10 h day/night cycle and $27 / 22^{\circ} \mathrm{C}$ day/night temperature). Natural day length (April to July) was supplemented and extended with incandescent illumination $\left(6 \mu \mathrm{E} \mathrm{s}^{-1} \mathrm{~m}^{-2}\right)$ at plant level. All plant ages were recorded as days after sowing. The pots were watered to field capacity twice a week, with a modified Johnson solution (Johnson et al. 1957) containing $8 \mathrm{mM}$ $\mathrm{NH}_{4} \mathrm{NO}_{3}$ and $0.1 \mathrm{mM} \mathrm{K \textrm {K } _ { 2 }} \mathrm{PO}_{4}$. In treatments referred to as high $\mathrm{P}$, the $\mathrm{KH}_{2} \mathrm{PO}_{4}$ concentration was $1 \mathrm{mM}$. Inoculation with AM fungus was performed by applying 300 to 500 spores of $G$. intraradices in a 1-cm-thick soil layer, $4 \mathrm{~cm}$ below the soil surface in the pots, prior to sowing. Control plants were treated in the same way except for the addition of spores; no fungal colonization was detected in the controls during the experiments. All experiments were performed at least twice and results corresponding to one representative experiment are given in the present paper.

At several times during invasion and colonization by the fungus, root samples were examined for mycorrhizal infection, by staining with a trypan blue solution (Phillips and Hayman 1970) and inspecting under a dissecting microscope (WILD Heerbrugg M8, Switzerland) according to the gridline intersection method (Giovannetti and Mosse 1980). The infected area of the root (as specified below) was collected from the original pots, immediately frozen in liquid nitrogen and kept at $-70^{\circ} \mathrm{C}$.

In experiments in which the synthetic chemical BTH (Friedrich et al. 1996) was used to induce the expression of PR proteins, the treated plants received a single application of the solution containing $50 \mathrm{ppm}$, by watering 4 days prior to the first sampling.

$N$. sylvestris plants constitutively expressing tobacco basic chitinase A transgene, line 1794C9-1, were kindly supplied by J. Ryals, Novartis Corp., Research Triangle Park, NC (Neuhaus et al. 1991; Alexander et al. 1993) and N. tabacum cv. Xanthi-nc constitutively expressing GUS, was kindly ob-

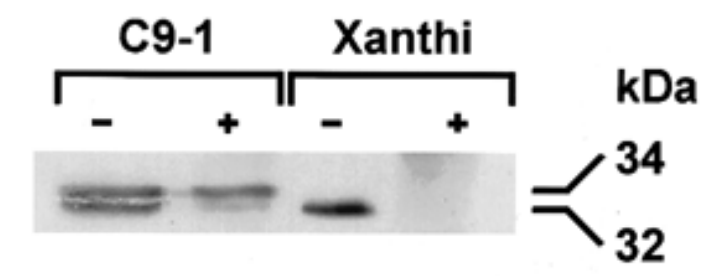

Fig. 9. Tobacco basic chitinase in transgenic and nontransgenic tobacco plants. Nicotiana sylvestris constitutively expressing the 34-kDa endochitinase A (C9-1 line) was infected with Glomus intraradices. Western blot (immunoblot) performed with $10-\mu \mathrm{g}$ protein samples from the mycorrhizal (+) and nonmycorrhizal (-) transgenic and $N$. tabacum cv. Xanthi-nc plants was probed with polyclonal antibodies directed against tobacco chitinase. The 34-kDa endochitinase A and the 32-kDa endogenous isoforms are indicated. 
tained from G. Galili, The Weizmann Institute of Science, Rehovot, Israel.

\section{RNA extraction and the differential display reaction.}

RNA from 42-day-old mycorrhizal roots (an infected area from 3 to $4 \mathrm{~cm}$ below the soil surface; with an infection rate of $70 \%$ ) and from noninfected roots was extracted according to De Vries et al. (1988), with the following modifications: the nucleic acids were precipitated with isopropanol; the resulting pellet was resuspended in $4 \mathrm{ml}$ of $2 \mathrm{M} \mathrm{LiCl}$ solution, incubated at 0 to $4^{\circ} \mathrm{C}$ for $16 \mathrm{~h}$, and centrifuged for $20 \mathrm{~min}$ at $12,000 \times g$; the RNA pellet was suspended in water, ethanolprecipitated, resuspended in water, and stored at $-70^{\circ} \mathrm{C}$.

Differential display reactions were performed according to Liang and Pardee (1992). The reaction that yielded the differential mycorrhizal band was as follows: $1 \mu \mathrm{g}$ of DNase-treated RNA was reverse transcribed in reverse-transcriptase (RT) buffer (Boehringer Mannheim, Mannheim, Germany) containing 20 units of RNase inhibitor (USB, Cleveland, OH), 2.5 $\mu \mathrm{M}$ T13C oligomer, $20 \mu \mathrm{M}$ dNTPs, and 30 units of MuLV RT (Boehringer Mannheim) for $1 \mathrm{~h}$ at $37^{\circ} \mathrm{C}$, followed by heatinactivation of the enzyme at $95^{\circ} \mathrm{C}$ for $5 \mathrm{~min}$. A $4-\mu \mathrm{l}$ aliquot of the RT reaction was subjected to PCR in the presence of $2 \mu \mathrm{M}$ dNTPs, $2.5 \mu \mathrm{M} \mathrm{T} \mathrm{T}_{13} \mathrm{C}, 0.5 \mu \mathrm{M}$ OPA8 primer (5'GTGACGT AGG, Operon Technology, Alameda, CA), $1 \mu \mathrm{l}$ of $\left[{ }^{35} \mathrm{~S}\right] \mathrm{dATP}$ (DuPont NEN, Wilmington, DE) and 2 units of Taq polymerase in a reaction buffer (Boehringer Mannheim). Reaction conditions, product analyses, and isolation were as described by Liang and Pardee (1992). The isolated, re-amplified band was blunt-ended with T4 polymerase (Promega, Madison, WI), ligated into the SmaI site of pBluescript (Stratagene, La Jolla, CA), and sequenced by the dideoxy chain termination method, with an automated DNA sequencer, dye terminators, and the standard T3 and T7 primers. Computer analyses of nucleotide sequences were carried out with software from the GCG/EGCG package of the University of Wisconsin, running under a UNIX system.

Preparation of tobacco basic chitinase gene-specific probe.

An 228-bp fragment that encodes the amino-terminal sequence of tobacco basic chitinase enzyme, containing only the cysteine-rich "hevein" domain and the hinge region, was obtained by the PCR method. Tobacco basic chitinase clone pCHN50 (Shinshi et al. 1987; GenBank accession number M15173) was subjected to amplification by means of a direct primer (5'CTCGGCAGAACAATGTGG) corresponding to nucleotides 21 to 38 , and a reverse primer (5'GTAGTTTCAT GGGAGG) corresponding to nucleotides 383 to 368 of that sequence. The reaction included $1 \mu \mathrm{M}$ of each primer, $200 \mu \mathrm{M}$ dNTPs, and 1 unit of Taq polymerase in a reaction buffer (Boehringer Mannheim). After 2 min of denaturation at $95^{\circ} \mathrm{C}$, the DNA was subjected to 30 amplification cycles of $94^{\circ} \mathrm{C}$ for 1 min, $52^{\circ} \mathrm{C}$ for $1 \mathrm{~min}$, and $72^{\circ} \mathrm{C}$ for $2 \mathrm{~min}$, followed by a final step at $72^{\circ} \mathrm{C}$ for $5 \mathrm{~min}$. The resultant 384-bp fragment was digested with $S p h \mathrm{I}$, yielding a 228-bp fragment, designated ChitB, that was hexamer labeled as described by Sambrook et al. (1989) and used as a specific probe for basic chitinase mRNA.

\section{Genomic DNA purification and Southern analysis.}

DNA extraction from spores of $G$. intraradices was performed according to Cummings and Wood (1989) with minor modifications. Since ground spores didn't mix well during incubation with cetyl trimethyl ammonium bromide (CTAB)/proteinase $\mathrm{K}$ lysis buffer, the incubation time was shortened to $30 \mathrm{~min}$ at $60^{\circ} \mathrm{C}$ followed by chloroform addition and further incubation for $30 \mathrm{~min}$ at $60^{\circ} \mathrm{C}$. Additional chloroform extraction was not needed. DNA concentration was determined by comparing its ethidium bromide (EtBr) staining intensity in a $0.7 \%$ TAE ( $40 \mathrm{mM}$ Tris-acetate, $1 \mathrm{mM}$ EDTA) agarose gel to a standard of phage lambda uncut genomic DNA. Tobacco DNA was purified similarly, omitting proteinase $\mathrm{K}$ from the CTAB lysis buffer. Two-microliter aliquots of DNA were subjected to BamHI and EcoRI restriction enzyme digestion, applied to a $0.7 \%$ TAE agarose gel and blotted to a nylon membrane (Hybond $\mathrm{N}^{+}$, Amersham, Buckinghamshire, UK) by alkali blotting according to the manufacturer's protocol. Hybridization was performed with the tomato rDNA fragment as described for Northern analysis.

\section{Northern blot analysis.}

RNA was extracted from a $1-\mathrm{cm}$ root segment from the infected area ( 3 to $4 \mathrm{~cm}$ below the soil surface), 25, 35, and 45 days after sowing, using Tri-Reagent (Molecular Research Center, Cincinnati, OH). Ten-microliter samples of total RNA were applied to a $1.1 \%$ formamide-agarose gel (Sambrook et al. 1989), followed by blotting to a nylon membrane (Hybond $\mathrm{N}$; Amersham). Hybridizations with Denhardt's reagent (Sambrook et al. 1989) were performed with ${ }^{32} \mathrm{P}$-labeled probes of MD17, ChitB, an oligomer homologous to nucleotides 102 to 127 of MD17, $1.8 \mathrm{~kb}$ of the GUS gene and a 1-kb tomato 25S rDNA fragment (kindly provided by E. Lifschitz, the Technion, Haifa, Israel) for normalization of the results. Blots probed with MD17 or the oligomer were washed three times with $3 \times \mathrm{SSC}(1 \times \mathrm{SSC}$ is $0.15 \mathrm{M} \mathrm{NaCl}$ plus $0.015 \mathrm{M}$ sodium citrate), $0.1 \%$ (wt/vol) sodium dodecyl sulfate (SDS) at $42^{\circ} \mathrm{C}$ for $20 \mathrm{~min}$ each time. Basic chitinase, GUS, and ribosomal probes were washed twice for 15 min with $2 \times$ SSC and $0.1 \%(\mathrm{wt} / \mathrm{vol}) \mathrm{SDS}$ at room temperature, and twice for $15 \mathrm{~min}$ with $0.2 \times \mathrm{SSC}$ and $0.1 \%$ (wt/vol) SDS at $65^{\circ} \mathrm{C}$. Blots were exposed to either X-ray film with an intensifying screen at $-70^{\circ} \mathrm{C}$, or to a Phosphor-Imager screen for quantification of radioactivity, using the Phosphor-Imager Program (Fujix BAS1500; Fuji, Tokyo).

\section{Protein extraction and Western blot analysis.}

Proteins were extracted from a $1-\mathrm{cm}$ root segment from the infected area ( 3 to $4 \mathrm{~cm}$ below the soil surface) 25,35 , and 45 days after sowing. Root tissue $(0.1 \mathrm{~g})$ was ground in phosphate-buffered saline (PBS) $\mathrm{pH} \mathrm{7.0,} \mathrm{containing} \mathrm{"Protease-}$ inhibitor-cocktail tablets" (Complete; Boehringer Mannheim) according to the manufacturer's protocol. A 10- $\mathrm{gg}$ sample of protein, as determined by Bradford assay (Bradford 1976), was loaded onto a $12 \%$ SDS-polyacrylamide gel in a Mini Protein II Dual Slab Cell (Bio-Rad, Hercules, CA) and transferred onto a nitrocellulose filter (Gelman, Ann Arbor, MI) with Mini Trans-Blot (Bio-Rad) according to the manufacturer's protocols. The filter was treated with $5 \%$ (wt/vol) milk powder in PBS containing 0.1\% (vol/vol) Tween 20 for $1 \mathrm{~h}$ at room temperature, prior to the addition of polyclonal antibodies directed against tobacco chitinases (kindly provided by R. Fluhr, The Weizmann Institute of Science, Rehovot, Israel.). After a 2-h incubation at room temperature, the unbound anti- 
bodies were washed with PBS containing $0.1 \%$ Tween 20 , and the filter was incubated with peroxidase-conjugated goat antirabbit IgG (Jackson ImmunoResearch Lab., West Grove, PA) for $30 \mathrm{~min}$. After subsequent washing with PBS containing $0.1 \%$ Tween 20, the filter was treated with an ECL Kit (Amersham) and exposed to X-ray film.

\section{ACKNOWLEDGMENTS}

We thank S. Wininger, R. Zaco, and H. Badani for their technical assistance, R. Fluhr for anti-PR3 polyclonal antibodies, F. Meins for the pCHN50 probe, and J. Ryals for transgenic tobacco and the gift of the BTH compound. This work was partially supported by GIF project no. G-0388-199.12.

\section{LITERATURE CITED}

Alexander, D., Goodman, R. M., Gut-Rella, M., Glascock, C., Weymann, K., Friedrich, L., Maddox, D., Ahl-Goy, P., Luntz, T., Ward, E., and Ryals, J. A. 1993. Increased tolerance to two oomycete pathogens in transgenic tobacco expressing pathogenesis-related protein 1a. Proc. Natl. Acad. Sci. USA 90:7327-7331.

Blee, K. A., and Anderson, A. J. 1996. Defense related transcript accumulation in Phaseolus vulgaris L. colonized by the arbuscular mycorrhizal fungus Glomus intraradices Schenck \& Smith. Plant Physiol. 110:675-688.

Boller, T. 1987. Hydrolytic enzymes in plant disease resistance. Pages 358-411 in: Plant-Microbe Interactions, Molecular and Genetic Perspectives, Vol 3. T. Koshuge and E. W. Nester, eds. Macmillan, New York

Boller, T. 1988. Ethylene and the regulation of antifungal hydrolases in plants. Pages 145-174 in: Surveys of Plant Molecular and Cell Biology, Vol 5. B. J. Miflin, ed. Oxford University Press, Oxford.

Boller, T., Gehri, A., Mauch, F., and Vogeli, U. 1983. Chitinase in bean leaves: Induction by ethylene, purification, properties, and possible function. Planta 157:22-31.

Bonfante-Fasolo, P. 1988. The role of the cell-wall as a signal in mycorrhizal associations. Page 219 in: Cell to Cell Signals in Plant, Animal and Microbial Symbiosis, NATO ASI Ser., Vol. 17. S. Scannerini, D. C. Smith, P. Bonfante-Fasolo, and V. Gianinazzi-Pearson, eds. Springer-Verlag, Berlin.

Bonfante-Fasolo, P., and Perotto, S. 1992. Mycorrhizal and pathogenic fungi: Do they share any features? Pages 256-273 in: Electron Microscopy in Plant Pathogens. K. Mendgen and D. E. Lesemann, eds. Springer-Verlag, Berlin.

Bradford, M. M. 1976. A rapid and sensitive method for the quantification of microgram quantities of protein utilizing the principle of protein-dye binding. Anal. Biochem. 72:248-254.

Broglie, K., Chet, I., Holliday, M., Cressman, R., and Broglie, R. 1991. Transgenic plants with enhanced resistance to the fungal pathogen Rhizoctonia solani. Science 254:1194-1197.

Collinge, D. B., Kragh, K. M., Mikkelsen, L. D., Nielsen, K. K., Rasmussen, U., and Vad, K. 1993. Plant chitinases. Plant J. 3:31-40.

Cummings, B., and Wood, T. 1989. A simple and efficient method for isolating genomic DNA from endomycorrhizal spores. Gene Anal. Technol. 6:89-92.

De Vries, S., Hoge, H., and Bisseling, T. 1988. Isolation of total and polysomal RNA from plant tissues. Plant Mol. Biol. Manual B6:1-13.

Dumas-Gaudot, E., Furlan, V., Grenler, J., and Asselin, A. 1992. New acidic chitinase isoforms induced in tobacco roots by vesiculararbuscular mycorrhizal fungi. Mycorrhiza 1:133-136.

Dumas-Gaudot, E., Guillaume, P., Tahiri-Alaoui, A., Gianinazzi-Pearson, V., and Gianinazzi, S. 1994. Changes in polypeptide patterns in tobacco roots colonized by two Glomus species. Mycorrhiza 4:215-221.

Friedrich, L., Lawton, K., Ruess, W., Masner, P., Specker, N., Gut-Rella, M., Meier, B., Dincher, S., Staub, T., Uknes, S., Metraux, J. P., Kessmann, H., and Ryals, J. 1996. A benzothiadiazole derivative induces systemic acquired resistance in tobacco. Plant J. 10:61-70.

Fukuda, Y., Ohme, M., and Shinshi, H. 1991. Gene structure and expression of tobacco endochitinase gene in suspension-culture tobacco cells. Plant Mol. Biol. 16:1-10.
Gianinazzi-Pearson, V., Gollotte, A., Lherminier, J., Tisserant, B., Franken, P., Dumas-Gaudot, E., Lemoine, M. C., van Tuinen, D., and Gianinazzi, S. 1995. Cellular and molecular approaches in the characterization of symbiotic events in functional arbuscular mycorrhizal associations. Can. J. Bot. 73:S526-S532.

Giovannetti, M., and Mosse, B. 1980. An evaluation of techniques for measuring vesicular arbuscular mycorrhizal infection in roots. New Phytol. 84:489-500.

Graham, L. S., and Sticklen, M. B. 1994. Plant chitinases. Can. J. Bot. 72:1057-1083.

Harrison, M. J., and Dixon, R. A. 1994. Spatial patterns of expression of flavonoid/isoflavonoid pathway genes during interaction between roots of Medicago truncatula and the mycorrhizal fungus Glomus versiforme. Plant J. 6:9-20

Johnson, C. M., Stout, P. R., Beyer, J. C., and Carlson, A. B. 1957. Comparative chlorine requirements of different species. Plant Soil 8 : 337.

Kapulnik., Y., Volpin, H., Itzhaki, H., Ganon, D., Galili, S., David., R., Shaul, O., Elad, Y., Chet, I., and Okon, Y. 1996. Suppression of defense response in mycorrhizal alfalfa and tobacco roots. New Phytol. 133:59-64.

Lambais, M. R., and Mehdy, M. C. 1993. Suppression of endochitinase, $\beta$-1-3-endoglucanase, and chalcone isomerase expression in bean vesicular-arbuscular mycorrhizal roots under different soil phosphate conditions. Mol. Plant-Microbe Interact. 6:75-83.

Lawton, K., Ward, E., Payne, G., Moyer, M., and Ryals, J. 1992. Acidic and basic class III chitinase mRNA accumulate in response to TMV infection of tobacco. Plant Mol. Biol. 19:735-743.

Liang, P., and Pardee, A. B. 1992. Differential display of eukaryotic messenger RNA by means of polymerase chain reaction. Science 257: 967-971.

Neale, A. D., Wahleithner, J. A., Lund, M., Bonnett, H. T., Kelly, A., Meeks-Wagner, D. R., Peacock, W. J., and Dennis, E. S. 1990. Chitinase, $\beta$-1-3-glucanase, osmotin and extensin are expressed in tobacco explants during flower formation. Plant Cell 2:673-684.

Neuhaus, J.-M., Sticher, L., Meins, F., and Boller, T. 1991. A short Cterminal sequence is necessary and sufficient for the targeting of chitinases to the plant vacuole. Proc. Natl. Acad. Sci. USA 88:1036210366.

Patterson, N. A., Chet, I., and Kapulnik, Y. 1990. Effect of mycorrhizal inoculation on nodule initiation, activity and contribution to legume productivity. Symbiosis 8:9-20.

Payne, G., Ahl, P., Moyer, M., Harper, A., Beck, J., Meins, F., and Ryals, J. 1990. Isolation of complementary DNA clones encoding pathogenesis-related proteins $\mathrm{P}$ and $\mathrm{Q}$, two acidic chitinases from tobacco. Proc. Natl. Acad. Sci. USA 87:98-102.

Phillips, J. M., and Hayman, D. S. 1970. Improved procedures for clearing and staining parasitic and vesicular-arbuscular mycorrhizal fungi for rapid assessment of infection. Trans. Br. Mycol. Soc. 55: 158-161.

Sambrook, J., Fritsch, E. F., and Maniatis, T. A, 1989. Molecular Cloning: A Laboratory Manual. 2nd ed. Cold Spring Harbor Laboratory, Cold Spring Harbor, NY.

Schlumbaum, A., Mauch, F., Vogeli, U., and Boller, T. 1986. Plant chitinases are potent inhibitors of fungal growth. Nature 324:365367.

Sela-Buurlage, M. B., Ponstein, A. S., Bres-Volemans, S. A., Melchers, L. S., van den Elzen, P. T. M., and Cornelissen, B. J. C. 1993. Only specific tobacco (Nicotiana tabacum) chitinases and $\beta$-1,3-glucanases exhibit antifungal activity. Plant Physiol. 101:857-863.

Shinshi, H., Mohnen, D., and Meins, F., Jr. 1987. Regulation of a plant pathogenesis-related enzyme: Inhibition of chitinase and chitinase mRNA accumulation in cultured tobacco tissues by auxin and cytokinin. Proc. Natl. Acad. Sci. USA 84:89-93.

Shinshi, H., Neuhaus., J.-M., Ryals, J., and Meins, F., Jr. 1990. Structure of tobacco endochitinase gene: Evidence that different chitinase genes can arise by transposition of sequences encoding a cysteine-rich domain. Plant Mol. Biol. 14:357-368.

Smith, S. E., and Gianinazzi-Pearson, V. 1988. Physiological interactions between symbionts in vesicular arbuscular mycorrhizal plants. Annu. Rev. Plant Physiol. Plant Mol. Biol. 39:221-244.

Spanu, P., Boller, T., Ludwig, A., Wiemken, A., Faccio, A., and Bonfante-Fasolo, P. 1989. Chitinase in roots of mycorrhizal Allium porrum: regulation and localization. Planta 177:447-455. 
van Buuren, M., Neuhaus, J.-M., Shinshi, H., Ryals, J., and Meins, F., Jr. 1992. The structure and regulation of homologous tobacco endochitinase genes of Nicotiana sylvestris and $N$. tomentosiformis origin. Mol. Gen. Genet. 232:460-469.

Vierheilig, H., Alt, M., Lange, J., Gut-Rella, M., Wiemken, A., and Boller, T. 1995. Colonization of transgenic tobacco constitutively expressing pathogenesis-related proteins by vesicular-arbuscular mycorrhizal fungus Glomus mosseae. Appl. Environ. Microbiol. 61: 3031-3034.

Vierheilig, H., Alt, M., Neuhaus, J.-M., Boller, T., and Wiemken, A.
1993. Colonization of transgenic Nicotiana sylvestris plants, expressing different forms of Nicotiana tabacum chitinase, by the root pathogen Rhizoctonia solani and by the mycorrhizal symbiont Glomus mosseae. Mol. Plant-Microbe Interact. 6:261-264.

Volpin, H., Elkind, Y., Okon, Y., and Kapulnik, Y. 1994. A vesicular arbuscular mycorrhizal fungus (Glomus intraradices) induces a defense response in alfalfa roots. Plant Physiol. 104:683-689.

Volpin, H., Phillips, D. A., Okon, Y., and Kapulnik, Y. 1995. Suppression of an isoflavonoid phytoalexin defense response in mycorrhizal alfalfa roots. Plant Physiol. 108:1449-1454. 